\title{
Oral History and Memory: A Personal Journey
}

\section{MARGARET RANDALL}

American-born writer, photographer, activist and academic. Born in New York City, she lived for many years in Spain, Mexico, Cuba, and Nicaragua, and spent time in North Vietnam during the last months of the U.S. war in that country. She has written extensively on her experiences abroad and back in the United States, and has taught at Trinity College in Hartford, Connecticut, and other colleges.

Abstract: Autobiographical essay by Margaret Randall on her experience as a cultural and social activist who focused part of her work in Oral History. "How I got into doing oral history was simple. The way I went about it responded to my lack of formal training-I had no university degree, wasn't an anthropologist or ethnographer. In line with my innate pragmatism, I wanted to know and so I asked”. 
How I got into doing oral history was simple. The way I went about it responded to my lack of formal training-I had no university degree, wasn’t an anthropologist or ethnographer. In line with my innate pragmatism, I wanted to know and so I asked.

Mexico, 1968-69. A perfect storm of events led me to this genre. I had come to the country eight years earlier: a young poet fresh from New York City. Although I began to engage politically in the New York of the late fifties, living south of the boarder taught me what my country of origin was doing to those peoples within its sphere of influence. I learned about neo-colonialism and imperialism not out of textbooks, but because I saw their wounds all around me. Then, in 1968, my participation in Mexico's Student Movement taught me the lengths to which a government will go to suppress dissent and preserve power. It was a shocking lesson. This is an extremely condensed version of how I acquired Leftist politics.

Feminism was the other component of that perfect storm. In the late $1960 \mathrm{~s}$ and early $70 \mathrm{~s}$, in urban centers in the United States and parts of Western Europe, women were coming into their own. Their insights and rage began appearing in articles, essays, and documents of all kinds. In Mexico City I read that material and its relevance to my own life was immediate and breathtaking. Suddenly I understood that issues I had believed to be personal were, in fact, social. The painful double standard of which I'd been a victim without really thinking about it unfolded before me: an "aha" moment in popular culture terms. From then on, women's lives became a primary interest. I wanted to know how different societies treated them and how they responded.

As a result of my participation in the Student Movement, I was eventually forced into hiding and, in 1969, fled Mexico for Cuba. Excited by the variety and depth of feminist writings, I'd collected those I thought most interesting and fashioned a small anthology. I wanted my sisters in Latin America to read this material that had meant so much to me. In 1970, Siglo XXI published the collection, and Las mujeres has gone into more than thirty editions. I arrived in Cuba, in the fall of 1969, with one question on my lips: Had socialism changed women's lives, and if so how? My first oral history project was born.

As I've said, I had no formal training. To my mind it was simple: if I wanted to know if the Cuban revolution was making women's lives different, I had to ask the women themselves. I was a very incipient feminist at the time, but most Cuban women had never even heard the word (which in the early years of the Cuban revolution would acquire a negative connotation). Establishing the nation's grass roots women's organization, the Federation of Cuban Women (FMC) had been, like so much else, Fidel Castro's idea. Vilma Espín, its first and long-time president, assumed her responsibilities almost grudgingly. As she told me when I interviewed her for that first book, initially she had seen no reason for 
Margaret Randall. Oral History and Memory...

a women's organization. She had accomplished what she set out to do. Couldn't other women do the same?

Cuban women had been profoundly involved in their country's social transformation, and it in turn had changed their lives dramatically. For two years I traveled everywhere, interviewing women of all ages and in a variety of activities. What I learned became La mujer cubana ahora, later translated into a number of languages and published in English as Cuban Women Now. My first book of oral history.

Although the term oral history already described a new genre-literatura testimonial, in Spanishthat had begun to emerge throughout the continent (especially where peoples' struggles were taking place), it was mostly used in the academic circles with which I had scant contact. After Cuban Women Now, I went on to write Somos Millones or Doris Tijerino: Inside the Nicaraguan Revolution and then a series of other texts, including Sueños y realidades de un guajiricantor, about a male peasant who wrote verse plays in décima form. Yet when I received a phone call from a Mexican historian, who had come to Cuba to update the compendium of oral historians published by her country's Museum of Anthropology and History, it was the first time I'd heard the words. I thought she had me confused with some kind of dentist.

I had several books of oral history to my credit before I'd read Manuela la mexicana (1968), Operación masacre (1957), Biografía de un cimarrón (1966) or any of the other early classics in the field. Only much later would I begin to participate in some of the polemics about the ethical questions implicit, the best ways to go about collecting and assessing one's material, what kind of additional research was necessary, and so much more. ${ }^{1}$ In other words, I became an oral historian before paying much attention to what that meant. The problems that arose as I worked on a particular projectand there were many-I solved pragmatically as I went along.

During those early years, I wasn’t all that conscious of memory. Looking back, I believe this was mostly because I had yet to explore the role of memory in my own life. Everything, for me, was rooted in acknowledged experience. And the experience of life in Cuba, and later in Nicaragua, was demanding. We were creating a new society. The obstacles were enormous. One might be a writer, as I was. One might write books about the experiences of others. But the requirements of everyday life-which in my case included a full-time job, mothering four children, participating in various mass organizations,

\footnotetext{
${ }^{1}$ On my first visit to Sandinista Nicaragua I was asked by the Ministry of Culture to give a brief practical course in oral history, one that would be useful for ordinary people wanting to document their country's social change as well as for academics. My lectures were later published in a small book called Testimonios (1983). An English version, also called Testimonios, appeared in 1985 from the Participatory Research Group in Toronto, Ontario.
} 
voluntary work and guard duty-were exhausting. We took short courses in Marxist economics, but it never occurred to me to study ethnography. I was doing it, and that was enough.

Or so I thought.

Apparently there were others who thought so too. Carolyn Nizzi Warmbold, at the University of Texas in Austin, later wrote her doctoral dissertation on Women of the Mosquito Press: Louise Bryant, Agnes Smedley, and Margaret Randall as Narrative Guerrillas. She postulated a lack of formal education as one of the reasons our work was so felt and fresh, when compared to other more academic writers who had done work based on interviewing people during periods of revolutionary change. Today I would say some of the richest writing in the genre comes from those who are able to draw on a solid academic background while being willing to risk moving beyond the safety of its often stifling restrictions.

In 1980 I left Cuba and went to Nicaragua, where the Sandinistas had just taken power. In 1984, after a quarter century in Latin America, I returned to the United States. All the while, I produced a number of other testimonial books, some of which-like Sandino's Daughters (1981), Sandino's Daughters Revisited (1994), Christians in the Nicaraguan Revolution (1983), Risking a Somersault in the Air (1984), The Price You Pay (1996) and When I Look Into the Mirror and See You (2002)became important to a broad spectrum of readers. It was back here, in the country of my birth, that I made the personal discovery that sent me in search of memory.

I came home in my late forties, traumatized by war and physically and mentally done in by working alongside people half my age. I needed to rest and reconnect with the familiarity of language, culture, and family. I had no idea I would be met with two new upheavals: a deportation order on the part of the U.S. government (they didn’t like what I wrote or the countries where I'd lived, and used the 1952 McCarranWalter Immigration and Naturalization Act to charge me with being "against the good order and happiness of the United States"), ${ }^{2}$ and the revelation of early childhood incest.

The former resulted in a five-year battle, which I waged with the help of devoted lawyers, dozens of solidarity committees across the country, and thousands of supporters from all walks of life. The rediscovery of incest was a more intimate experience. I was seeing a therapist to help with the challenges in my life; and it was in a session with her that previously obscured memories of what my grandfather had done to me began to emerge. Those memories explained a lot, at a time when I barely had time for such personal inquiry.

${ }^{2}$ See Randall (1990) for a long essay on my immigration case. 
As was by then my practice, I began writing a book: doing oral history with myself as it were. This is About Incest ${ }^{3}$ was one of the first texts about childhood sexual abuse in what would soon become a vivid and comprehensive literature on the subject. I used the work in my therapist's office, old photographs, and poetry to explore what had been perpetrated against me, and begin to heal. Intense memory work placed the idea of memory itself front and center.

Eventually the subject of memory became a passion. I wanted to know what exactly it is (scientifically as well as psychologically, emotionally, politically, and historically), where in the body it resides, how it works, what can erase or temporarily delay it, and in whose interests it may be to dull or trivialize its findings. I wanted to know if it is gendered, differs between ethnicities and cultures or through time. And by now I knew how to make use of what others before me, in a variety of fields, had contributed to the field. I read and read. Judith Lewis Herman and Alice Miller ${ }^{4}$ were particularly important.

I learned about the similarities between so-called domestic violence and the trauma of war. It occurred to me that the invasion of a child's body by an adult with power over that child's life has a great deal in common with the invasion of a small country by one that is larger and stronger. The abuser employs similar mechanisms of control; the abused show similar symptoms of fear, self-hatred and immobilization. Only the scale is different.

All around me I perceived the ways in which the system, from its educational curricula to the evening news and commercial advertising, depends upon memory erasure to obtain its goals. From my own feminist practice and analysis-and that of others-I understood that until we remember who we've been, we aren't likely to be able to choose who we want to be.

Out of a life like mine it's logical that my interest in memory should mesh with my passion for learning how people live and what they think and feel; particularly women, since our thoughts and feelings have been ignored and ridiculed for centuries. It is an interest that has paralleled my own woman's consciousness. In fact, I was heading in this direction long before I was able to articulate it through my discovery of incest. My later books-of essay and poetry as well as oral history-go much deeper into the intersection of memory and everyday life.

In recent years, two other areas invite exploration. One is the role memory and voice play in my poetry. The other is the way in which memory has drawn me to sites of ancient life. Of the former there are many examples; one need only go to some of my poetry collections-most notably This is About

$\underline{3}$ This is About Incest, Ithaca, New York, Firebrand Books, 1987.

${ }^{4}$ I refer to Judith Lewis Herman's Trauma and Recovery, and Alice Miller's Trauma of the Gifted Child, among others. 
Margaret Randall. Oral History and Memory...

Incest, Where They Left You for Dead / Halfway Home (2001), Stones Witness, Their Backs to the Sea (2009), My Town (2010), Ruins (2011), The Rhizome as a Field of Broken Bones (2013), and About Little Charlie Lindbergh (2014). The poems are conversational and frequently include quotes or passages of authentic speech.

But there is another reason why memory also inhabits my poems very differently today than it did years ago. As we age, many of us experience problems with short-term memory. My father died of Alzheimer's, so I've sometimes wondered if I might be heading down senility's road. I'm more likely, though, to ascribe the momentary lapses to the stress of these dangerous times, the burden of economic turmoil, and the pollutants we ingest from air, water, food and industrial waste.

I often sit before my computer monitor searching for a misplaced word, waiting in vain for it to surface. I've learned to cut my frustration by marking the troubling place with a dash and moving on. More often than not the word gives up and comes to me. But I can also speak of a positive side to age and memory. In my poetry in particular, my body remembers rhythm, cadence and breath line in much the same way it remembers how to walk or make love; long-nurtured capabilities are deeply imprinted. Accessing the body memory seems to be easier as I age. This is difficult to describe unless you have experienced it.

At the moment my interest in the nature and role of memory plays itself out against the backdrop of ongoing visits to ancient ruins. Many of these are the sites of Ancestral Puebloan life in my own Southwest. Visits to Kiet Seel, Wupatki, Mesa Verde, Hovenweep, Paquimé (in northern Mexico), and the thousands of places where peoples who lived millennia ago left their art on canyon walls, continue to raise questions about memory for me: How did cultures without a written language pass knowledge from one generation to the next? What relationship might there be between the silence of those canyons and voices we can only imagine today? What was the practical meaning of what we call "rock art?" How does the memory of long-ago lives function in today's descendants? Can we assume that memory is only linear?

Some of the sites that draw me are also in other parts of the world, evidence of cultures with which my connection is sensed rather than specified. Why do I feel so drawn to Palenque in Chiapas, Tikal in Guatemala’s Petén, Petra in Jordan, Kom Ombo in Egypt, Perge in Turkey? Why, when looking down from Athens' acropolis to the agora below, do I imagine myself in passionate discussion with Socrates? What do I myself remember, and how?

In fact, I have come to believe that memory is neither unidirectional nor finite. In ways I have best expressed through poetry, I am convinced we remember the future as well as the past, or, in the words of 
John Wheeler, that "the universe is built like an enormous feedback loop, a loop in which we contribute to the ongoing creation of not just the present and the future but the past as well." 5

Oral history, the testimonial novel or short story, personal narrative, and poetry with a strong component of personal experience and/or dialog, have all developed with their respective characteristics and ever-changing rules. As genres they owe a great deal to the individuals, places, and struggles that produce them. Those fighting for justice naturally privilege the words of ordinary men and women, their own telling of their history rather than a version told by historians who almost always represent a dominant class and culture.

It is often through these testimonies that we come to understand what really happened at a particular time, in a particular place. For example, those who didn't experience it for themselves could not have imagined Mexico's terrifying repression of October 1968 without Elena Poniatowska's La Noche de Tlatelolco (1971), The Night of Tlatelolco; and that book was the first to break the silence in which the offending government was able to shroud the event for several years.

Similarly, the poetry of Nicaraguan Ernesto Cardenal is powerful and eloquent in its reliance on the voices of ordinary people. When Cardenal was Minister of Culture in Sandinista Nicaragua, he created a nationwide network of workshops to form a whole school of testimonial poetry. Here in the United States, over the past couple of decades, women poets-most notably women of color-have led a sea change in a poetic expression with these characteristics. I think of Audre Lorde, June Jordan, Grace Paley, Joy Harjo, Lucy Tapahonso, Sonia Sánchez, and so many others.

It's also no accident that feminist thought and practice have contributed to defining the why's and how's of doing oral history. Ruth Bejar ${ }^{6}$ and other oral historians have posed questions and offered provisional answers that continue to enrich the field. In giving voice to others we are learning to be clear about our own backgrounds and biases so our points of view will be understood. We experiment with forms of organization and presentation that offer the most immediate access to the experiences we convey.

From the beginning, my own work ethic has included making sure my informants have the opportunity to read my transcription and editing of their words before publication. I have also most often shared any financial rewards with them. One of the women whose story I told in Cuban Women Now was Grandma, an elderly tobacco house worker in the westernmost province of Pinar del Río. She had never really learned to read or write, so before preparing the final version of my manuscript I went

\footnotetext{
${ }^{5}$ As quoted in Folger (2000).

${ }^{6}$ Ruth Bejar's seminal book was Translated Woman, in which she first addressed the issue of establishing one's own background when transmitting the voices of others.
} 
back to visit and read her chapter aloud. It was important to know where she felt she was being accurately represented and where she might want to make changes.

The oral history field has not been without its conflicts. Rigoberta Menchú's extraordinary first book $^{7}$ was attacked by an academic intent upon using what he perceived as contradictions in her storyline to disprove its authenticity. He was incapable of understanding the indigenous "we," or how severe trauma may affect memory. ${ }^{8}$ Other testimonies have also been criticized by those who prefer a purely chronological, research-based, and distanced telling.

I grappled with some of these issues for the first time when I worked with Nicaraguan revolutionary Doris Tijerino on the book that would become Somos millones. Doris came to my Havana apartment every morning for close to a year. It was a painful time for her. She had just learned that the father of the child she carried in her womb had been tortured to death back home.

We would talk and then tape her story, trying as much as possible to move along in the order in which the events took place. I transcribed those sessions every afternoon, and would have pages ready for her to go over the following morning. The complexity of Doris' story made me realize, early on, that I didn't want to produce one long interview. I wanted to find a way to present her story much as life presents itself: with all its layering and double-takes. At the time I was too inexperienced to be able to do more than group the pieces of Doris' story under headings signaling different areas: childhood, coming to terms with the necessity of struggle, her situation as a woman among men, and so on.

In later books, most notably When I Look Into the Mirror and See You, I would find the circular format I believe is better able to tell such a story. But this book proved difficult in yet another way. I'm generally quite disciplined and capable of moving through a project from beginning to end, becoming involved to the exclusion of almost everything else. When I Look Into the Mirror and See You was an exception. I'd been working on the book for several years when I decided I might not be able to finish it. The break-through for me came with the realization that this couldn't simply be a book about its two protagonists; I had to allow myself to be present as well.

By this time I was deeply concerned with memory, including cellular memory which was just then beginning to be acknowledged by psychotherapists and neurologists. The idea that violence to the body is stored in the cells and can be accessed, even years later, when the person is able to take the memory on, was central not only to the story I was telling but also to my own. I had always removed myself as much as possible from my books of oral history. Now I had to find the courage to make the connection in print. When I could do that I was able to complete the book.

7. Eventually published in many languages.
${ }^{8}$ David Stoll laid out his attack in 1999 (almost two decades after Menchú's text). 
In January 2011 I was invited to Cuba to be a judge at that year's Casa de las Américas contest, in the category of testimonio. In $1970 \mathrm{I}$ had judged the yearly contest for the first time, then in the poetry category. My hosts joked, saying they intended to invite me once every 41 years. It was particularly interesting for me to read the recent testimonio submissions, because it gave me an opportunity to see what is being done in that genre, particularly in Latin America. After reading all the manuscripts, and even after helping to bestow the prize on a very good one, I felt less enthusiasm for the genre than previously. I think this is because there is quite a bit of crossover among literary genres these days, and oral history techniques are frequently used in books not strictly called such.

The foregoing barely scratches the surface of oral history and memory. I hope it provides an outline of one writer's experience. 
Margaret Randall. Oral History and Memory...

\section{Bibliography}

Barnet, Miguel (1966). Biografía de un cimarrón. Havana: Instituto del libro.

Burgos-Debray, Elizabeth (1982). Me llamo Rigoberta Menchú y así me nació la conciencia. Havana: Casa de las Américas.

Folger, Tim. “Does the Universe Exist if We're Not Looking?”. Discover Magazine. (June 2000): 44-45.

García Alonso, Aida (1968). Manuela la Mexicana. Havana: Casa de las Américas.

Poniatowska, Elena (1971). La noche de Tlatelolco. Mexico DF: Siglo XXI.

Randall, Margaret (1972). La mujer cubana ahora. Havana: Cuban Book Institute.

Randall, Margaret (1974). Cuban Women Now. Ontario, The Women’s Press.

Randall, Margaret (1975). Spirit of the People: Vietnamese Women Two Years from the Geneva Accords, Vancouver: New Star Books.

Randall, Margaret (1977). Somos millones, la vida de Doris María, combatiente nicaraguense. Mexico City, Extemporaneos.

Randall, Margaret (1978). Doris Tijerino, Inside the Nicaraguan Revolution, Vancouver: New Star Books.

Randall, Margaret (1978b). El pueblo no solo es testigo: la historia de Dominga, Río Piedras: Puerto Rico.

Randall, Margaret (1978c). No se puede hacer la revolución sin nosotras, Havana: Casa de las Américas.

Randall, Margaret (1981). Sandino’s Daughters. Vancouver: New Star Books.

Randall, Margaret (1983). Testimonios. San José: Alforja Centro de Estudios de Participación.

Randall, Margaret (1983b). Christians in the Nicaraguan Revolution. Vancouver: New Star Books, 1983.

Randall, Margaret (1984). Risking a Somersault in the Air: Conversations with Nicaraguan Writers. San Francisco: Solidarity Publications.

Randall, Margaret (1990). Coming Home: Peace Without Complacency. Albuquerque: West End Press.

Randall, Margaret (1994). Sandino’s Daughters Revisited, New Brunswick: Rutgers University Press. 
Randall, Margaret (1996). The Price You Pay: The Hidden Cost of Women's Relationship to Money. New York: Routledge.

Randall, Margaret (2001). Where They Left You for Dead / Halfway Home. Berkeley: EdgeWork Books.

Randall, Margaret (2002). When I Look Into the Mirror and See You: Women, Terror, and Resistance. New Brunswick: Rutgers University Press.

Randall, Margaret (2007). Stones Witness. Tucson: The University of Arizona Press.

Randall, Margaret (2009). Their Backs to the Sea, San Antonio: Wings Press.

Randall, Margaret (2010). My Town. San Antonio: Wings Press.

Randall, Margaret (2011). Ruins. Albuquerque: University of New Mexico Press.

Randall, Margaret (2013). The Rhizome as a Field of Broken Bones, San Antonio: Wings Press.

Randall, Margaret (2014). About Little Charlie Lindbergh. San Antonio: Wings Press.

Randall, Margaret; Moreno, Ángel Antonio (1979). Sueños y realidades de un guajiricantor. Mexico D.F. : Siglo XXI.

Stoll, David (1999). Rigoberta Menchú and the Story of All Poor Guatemalans._Colorado: Westview Press.

Walsh, Rodolfo (1957). Operación masacre. Buenos Aires, Ediciones Sigla. 